\title{
Por Uma LeITURa Rizomática
}

\author{
Daniel Lins* \\ dlins@secrel.com.br
}

Resumo: Proposta de uma leitura norteada pela experimentação de um pensamento-acaso, pensamento nômade. A ideia de uma leitura rizomática permite conceber que a manifestação dos saberes não acontece necessariamente de modo "consciente". Trata-se de fazer emergir e alcançar platôs, dobras e linhas de fuga de um pensamento-outro, pensamento da diferença, instigando o leitor a interagir no vasto oceano de sonoridades e invenção de novos afectos, tornando-se, à medida que ler, o autor/leitor do próprio livro, aqui compreendido como um livro por vir.

Palavras-Chave: Leitura, rizoma, Internet, alfabeto, surfe.

O que é o rizoma? O rizoma é feito de platôs: "Um platô está sempre no meio, nem início nem fim, o rizoma é um sistema a-centrado não hierárquico e não significante, sem General, sem memória organizadora ou autômato central [...]" (DELEUZE; GUATTARI, 2000, p. 33).

O rizoma, como o platô, está sempre no meio, intermezzo, interser; sem alto nem baixo, sem começo nem fim: um ponto do rizoma é conectado a todos os outros pontos fazendo do livro um imenso manguezal, sem fim nem começo, que se espraia em um entrelaçamento de proteínas, calorias, gazes, lama, gozos, prazeres, detritos e... ouro - o caranguejo, em particular, e os crustáceos, em geral, são o ouro dos mangues -, esquecimento ativo e devires, nem simbiose nem filiação, mas alianças, intercessões, vizinhanças. O livro, como o rizoma, é uma antigenealogia:

Oposto à árvore, o rizoma não é objeto de reprodução: nem reprodução externa como árvore-imagem, nem reprodução interna como a estru-

\footnotetext{
* Professor da Universidade Federal do Ceará. Filósofo e Sociólogo. Dedicatória: Para Terence Adrien Lins, surfista que me ensinou a entrar em alianças com as ondas, ao invés de querer esposá-las.
} 
tura-árvore. O rizoma é uma antigenealogia. É uma memória curta ou uma antimemória. $O$ rizoma procede por variação, expansão, conquista, captura, picada. Oposto ao grafismo, ao desenho ou à fotografia, oposto aos decalques, o rizoma se refere a um mapa que deve ser produzido, construído, sempre desmontável, conectável, reversível, modificável, com múltiplas entradas e saídas, com suas linhas de fuga (DELEUZE; GUATTARI, 2000, p. 32-3).

Semelhante à Internet, o rizoma é a coisa conectada a qualquer instante, em qualquer lugar, em todas as línguas, segundo a criatividade de uma gramática das invenções: eixo primordial da leitura rizomática e, sobremaneira, sua força nômade, aquilo que chamo de o novo, o que está por vir. Neste sentido, o hipertexto se aproxima também do conceito de rizoma elaborado por Deleuze e Guattari. De modo textual, o hipertexto é feito de palavras e, às vezes, de imagens e sons. Aqui não se fala mais de "escritor", "autor", mormente, de técnico ou "criador". O criador organiza um espaço textual no qual o leitor o acompanha, pois participa do movimento da narração.

O computador, hóspede do hipertexto, torna-se um espaço museológico da memória, um espaço virtual que solicita a participação da criatividade do leitor. É uma obra aberta; um saber em uma rede reconfigurável composta de vínculos e intertextualidade. O texto é produzido em fragmentos, é uma obra feita de trajetórias na qual a ideia de "obra única", de autor solitário, parece deslocada. Já o livro eletrônico, sob formato de hipertexto, se resume em rede, liberando o texto confinado do interior do livro. Isso permite um conjunto e uma travessia de enunciados fazendo sair o livro do lugar fechado. Esse livro total, Mallarmé havia pensado em Igitur, projeto inacabado: um texto fechado no interior das páginas de um livro pode tão-somente aspirar a deixar sua prisão (MALLARMÉ, 1976).

A abertura é a força maior da partilha. Um texto impresso é uma rede que põe em relação enunciados verbais em um número limitado de páginas. Como um leitor perdido no mundo imaginado de seu romance, aquele que parte à busca de redes virtuais é o leitor reconhecendo o modelo da evasão na leitura, buscando a necessidade de se encontrar na Biblioteca de Babel à margem da realidade, despojado de todo envelope aprisionador, salvo quando o real torna-se legível e, de súbito, pode-se escrevê-lo. $\mathrm{O}$ mundo passa, então, a ser um "livro aberto", um livro para ser lido e escrito. O texto eletrônico, por sua vez, se organiza também em rede, entretanto, é instável, muda e, sobretudo, não admite nenhuma hierarquia, nenhum General nem Significante, é rizomático. Dele não se conhece nem começo, nem fim 
determinados; entra-se sempre pelo meio como em uma região "contínua de intensidades, vibrando sobre ela mesma, e que se desenvolve evitando toda orientação sobre um ponto culminante ou em direção a uma finalidade exterior" (DELEUZE; GUATTARI, 2000, p. 33).

O NOVO COMO CRIAÇÃO ÓRFÃ

O novo nasce de uma solidão acompanhada. Mormente, para que o novo aconteça é preciso que haja o esquecimento, uma memória das palavras. Eis, pois, toda sua dinâmica: o que é (a memória) dá lugar ao que não é ainda (o novo, que implica o esquecimento). O novo é o devir, é o por vir, como a mônada, ele poder ser percebido como uma multiplicidade contida na unidade. Não fazer história, mas monadologia. Não fazer raízes, mas rizoma, abertura para a imanência em um eterno retorno em que o que retorna são os blocos de diferença, numa gagueira interminável, numa repetição e apagamento em um tempo estratigráfico, um tempo da simultaneidade e da co-presença não contraditória dos problemas filosóficos e dos acontecimentos, todo o contrário, pois, da cronologia. É o próprio real que aparece como produção do novo, o que supõe uma passagem do agente - itinerante, por definição - por uma experiência singular. O novo, cuja força maior é seu caráter primitivo ou imediato da novidade, ora posto pela experiência, ora pelo ser, não significa que ele se apresente espontaneamente nem que seja reconhecido imediatamente como tal pelo pensamento, mesmo porque o pensamento, muitas vezes dependente da opinião, é impotente para acolher o novo.

O princípio de orfandade do novo, com seus dispositivos e forças criativas, rizomáticas supõe, pois, uma memória das palavras, uma cartografia nômade, movediça, produtora de uma leitura que inventa a própria leitura, com suas linhas de fuga e errância dos sentidos, numa heterogeneidade que é singularidade múltipla e abertura para o devir-leitor, devir-inventor do próprio do texto. Heterogêneo, o texto convoca simultaneamente seu leitor para múltiplas direções, para sua parte significativa - sentidos do texto -, imagens veiculando referências ao mundo, mas também para seu componente não diretamente representativo: ritmo, sonoridades, visualização imaginária, atual/virtual da imagem. Esse aspecto é muito importante: como fica a percepção de um texto enquanto experiência puramente sensorial da leitura, e não como compreensão de uma significação, nem recepção psíquica ou afetiva?

De fato, se há um processo de subjetivação do leitor, inserido no campo da afetividade e das afecções, não existe estritamente nada de sentimental 
nem emocional, mesmo porque o leitor é aqui multiplicidade: mais bando ou matilha que sujeito psicológico. Essa afetividade não é um estado de espírito nem um sentimento colonizado, mas uma ética das sensações ou dos afectos: eis a importância de pontuar a diferença entre afecto e afeto. Afecto é da ordem do desejo, ao qual nada falta: nem falta nem excesso, nem falta da falta, é o conatus de Espinosa. Afeto é da ordem do trauma, da falta, da demanda constante de amor, é uma produção psicológica de um sujeito atrelado à árvore, à origem, à estrutura, ao começo e ao fim. É o sujeito linear por excelência. $\mathrm{O}$ afecto e não a afetividade, gera uma leitura-outra, outramente. A produção de sentidos e não de significados - representações calcinadas - é algo inserido na singularidade do sujeito multifacetado: sujeito em devir que tenta interrogar o silêncio de uma escrita dominada pela linguagem (LINS, 2004).

Ora, o leitor em sua errância, marcado por uma ontologia sísmica, advém primeiro em seu ato de leitura. Embora seja tocado, atravessado pelo significante que afronta, o leitor não se extenua nesse desafio. Que faz ele, então? Experimenta. Embaralha os códigos, produz linhas de fuga para não morrer sufocado pelas significações que ditam aquilo que se deve sentir ou imaginar. Mas, se os sentidos de um texto se fazem e se desfazem continuamente, seria vão querer fixá-los: "A ausência de significado transcendental expande ao infinito o campo e o jogo da significação" (DERRIDA, 1967, p. 411).

Em todo experimento existe uma linha artística, ou linha envenenada: prudência, pois, para não "afugentar os devires". Neste contexto, as observações de Barthes instigam o leitor à prática de uma ética criativa da prudência. Ele insiste sobre a particularidade da leitura: se a figura do leitor se afirma como um dos lugares de produção da unidade multiplicadora do texto, cabe todavia renunciar à ilusão de uma semelhança entre a crítica e a leitura na medida em que ambas não exprimem o mesmo tipo de desejo:

Ler é desejar a obra, é querer ser a obra, é recusar duplicar a obra fora de qualquer outra palavra que a própria palavra da obra [...] Passar da leitura à crítica é mudar de desejo, é desejar não mais a obra, mas sua própria linguagem. E, assim, remeter a obra ao desejo de escrita do qual ela havia saído (BARTHES, 1999, p. 85).

Querer ser a obra não é o mesmo que querer comer a obra? Deveras, essa possível antropofagia, sem ressentimento nem mimetismo, é a situar na relação com o roubo, segundo um alfabeto intuitivo que trabalha com o acontecimento virtual atualizado em estados de coisas que necessariamente 
não o representa, pois que a atualização não é uma imitação, mas uma diferenciação. Nem gramática nem língua do pensamento, mas alfabeto. Por que? Sem dúvida, por causa de sua natureza virtual, enquanto a "gramática", "a língua", a "linguagem" remetem a estados de coisas, a domínios determinados, atualizados, "O alfabeto se compõe tão-somente de virtualidade daquilo que advirá uma gramática ou uma linguagem em tal ou tal domínio. $\mathrm{O}$ alfabeto não é tão pouco um modelo nem suas expressões cópias. $\mathrm{O}$ modelo é fixo e um, e suas cópias reproduzem sua unidade e sua estrutura. $\mathrm{O}$ alfabeto é movediço, diferenciando-se sem cessar, ao passar de virtual para atual, ou de um domínio expressivo para outro: pequenos deslocamentos de termos, precisões atribuídas aos conceitos, abandonos e adjunções de outras noções marcam as transformações que sofre de um texto a outro, de uma obra a outra" (GIL, 2006, p. 26).

Consequentemente, o mímico que é encarregado de realizar os deveres éticos não é o heroi da re-presentação do mesmo, ou ainda o kantiano que "repete" a máxima até que o imperativo categórico torne-se uma lei da natureza. $\mathrm{O}$ mímico deleuziano vê-se atribuir a dupla obrigação de desmascarar a máscara da máscara, as pretensões do atual a ser o único jogador e a re-ativar o virtual em seu processo infinito de diferenciação em relação a si mesmo: "Aquilo que queres, queira-o de tal modo que queiras também o eterno retorno", eis um imperativo nietzschiano, repetido inúmeras vezes por Deleuze (DELEUZE; GUATTARI, 1991, p. 151).

Direi, pois, que é somente no caso do acontecimento puro que a repetição pode ser compreendida como uma condição para a liberdade. A repetição é como um festival que repete aquilo que não pode recomeçar; "não com o objetivo de multiplicar o original, antes para elevar a primeira vez à enésima potência uma vez por todas e por todas as vezes. A repetição da qual é questão aqui é alcançada graças ao processo de contra efetuação" (BOUNDAS, 2005, p. 38).

Cabe, pois, falar de repetição desde que se aluda à repetição "alcançada graças ao processo de contra-atualização do atual”, isto é, vale mais querer e pensar o elemento virtual inerente ao acontecimento puro (DELEUZE, 1968 , p. 384; 1969, p. 175, 188, 209, 210).

Roubar o que se ler, roubar a produção de um texto ou de um pensamento não é, segundo Deleuze, uma maneira de enrabar, de fazer um filho por trás no autor, no pensador, no escritor? Ao contrário do falso perverso que passa sua vida a imitar, ao invés de enrabar, roubar, o perverso é aquele que não imita. Seu roubo nada tem a ver com o retorno do recalcado: o que aqui retorna é o novo, o inédito, aquilo que estava 
semelhante às múltiplas raízes dos rizomas (sem raiz-mãe), que cada um modula, à sua maneira, na sua diversidade e especificidade sensorial. Cada corporeidade é, pois, regida por um mecanismo de "agenciamento de temporalização" que pode ser sonoro, visual, táctil, gustativo. Mecanismo chamado por Deleuze e Guattari de ritornelo, na medida em que a emissão sonora dos cantos repetitivos, todavia diferentes, manifesta e simboliza perfeitamente esta gestão temporal fundamental. Assim, o ritornelo é "o conteúdo propriamente musical, o bloco de conteúdo próprio à música" e a dança como poesia e sensações errantes. Escrita dançante das sensações que exige do leitor uma orelha musical, sonora, e um corpo em movimento.

Silvio Ferraz, em uma bela e instigante criação intitulada Ritornelo: Composição passo a passo, propõe uma definição de ritornelo que no presente contexto nos convém perfeitamente:

O ritornelo caracteriza-se pelo movimento de eleger um eixo, de traçar um espaço em volta deste eixo, de deixar com que alguns elementos se estratifiquem e se crie a consistência necessária para tornar expressivos três elementos, quando então encontra uma linha vertiginosa que quase desfaz tudo: um corte, um acidente, uma sensação qualquer que não estava ali antes. O acidente não é uma projeção do passado (por exemplo, um tempo que se projeta ao longo de uma peça e que garante um primeiro chão), nem recai sobre um presente permanente (reiteração contínua), mas a possibilidade de conexões com o 'futuro', com linhas de conexões que não estavam previstas no modelo original, e que por sinal desfazem a ideia de original de referência - visto que cada momento passa a ser um espaço de conexões originais, mas de originais transitórios (FERRAZ, 2004, p. 63).

Umberto Eco, por sua vez, temendo que se chegasse a uma espécie de relativismo absoluto, segundo o qual todas as leituras são iguais, aponta algumas dificuldades próprias ao texto, que não devem ser subestimadas: Um texto 'aberto' é ainda um texto, e um texto suscita infinitas leituras sem por isso autorizar qualquer leitura possível (ECO, 1992, p. 130).

Leitura/escrita, Leitor/autor: dualidade ou núpcias e alianças ? "Se há uma unidade da leitura e da escrita [...], se a leitura é escrita, essa unidade não designa nem a confusão indiferenciada nem a identidade confortadora [...] Seria necessário, pois, de um só gesto, mas desdobrado, ler e escrever [...] O suplemento de leitura ou de escrita deve ser rigorosamente solicitado pela necessidade, contudo, de um jogo, signo ao qual é preciso atribuir o sistema de todos seus poderes" (DERRIDA, 1986, p. 3-4). 
por vir no pensamento do autor/leitor. Não foi isso que Deleuze fez com Espinosa, Leibniz, Nietzsche ou Artaud, Melville ou Fitzgerald?

O bom leitor não promete, pois, fidelidade a seus intercessores, mas traição. Não se trata de plágio, porém, de roubo. Ele quer encontrá-los, tecer com eles conexões singulares, sob o signo de uma originalidade incestuosa, errante, monstruosa, navegante, transitória embora não afaste a ideia de uma previsão, um plano prévio, mas que não segue a lógica da causa e do efeito : "Encontrar é achar, é capturar, é roubar, mas não há método para achar, nada além de uma longa preparação. Roubar é o contrário de plagiar, de copiar, de imitar ou de fazer como" (DELEUZE; PARNET,1998, p. 15).

Entrançamento de uma criação inorgânica, em que a sonoridade do texto torna-se barqueiro, a escrita-leitura-bailarina repercute nos gestos os excessos, a violência, a fascinação; aqui, a virgula, o ponto e virgula, a exclamação são os dedos dos pés e pensadores bailarinos que ritmam os versos e aforismos do corpo liso numa vastidão de dobras sem dentro/ fora nem fora/dentro, fazendo da leitura, da escrita-sonora, um puro rizoma. O silêncio do olho é ainda corpo-leitor-inventor em movimento, é diferença que difere, inserida em núpcias, em alianças, sob a força de um pensamento que é puro acaso: "Pensar é lançar os dados", eis a bela definição de Deleuze.

Previsão, condição e processo são tão-somente temporalidades sem genealogia nem memória totalizadoras, ou síntese de instantes, antes matriz de produção de cada um ao mesmo tempo idêntica/diferente, singularidade/multiplicidade, lisa/estriada, a leitura-bailarina é o Uno grávido de diferenças e singularidades, ou constelação de conceitos, contaminadas por uma ontologia sísmica que faz do Uno uma multidão, uma matilha, uma "Máquina de Guerra" - estética/ética do acontecimento. Ética do acontecimento alheia a uma obrigação infinita, antes voltada para a busca de meios visando multiplicar as potências da existência e intensificar a vida, inserindo, sobremaneira, os afectos nas relações entre as formas de vida.

Neste contexto, o leitor-bailarino não busca dominar, fechar, hierarquizar essa produção, mas entrar em núpcias com ela, numa aparente passividade consentida, no surgimento imprevisível de um devir fundamentalmente heterogêneo das naturezas dançarinas às quais pertencemos, habitadas por uma desumanização, um inumano que encontra no Corpo sem Órgãos seu aliado, visão que recorta a teoria rizomática ou maquínica de Deleuze e Guattari, exposta em Mil Platôs.

Há na natureza um processo de diferenciação radical imanente a um devir de forças materiais que constitui uma trama intensiva e selvagem 
Os sentidos são as pedras de uma fachada abrigando uma vida desconhecida da qual pode-se tão-somente desconfiar de sua riqueza e processo contínuos de desterritorialização. Lidar com os sentidos é um risco, e o leitor precisa correr risco para engendrar sua própria leitura e se engajar, para além da materialidade das palavras, numa leitura desejante cuja escrita é o traço, o corpo: presença de uma ausência, isto é, sentido que se imprime, sob o olhar do leitor, como a marca de um alhures que demanda tão-só se encarnar num presente que é atual/virtual: o atual designa o estado de coisas material e presente. $\mathrm{O}$ virtual designa o acontecimento incorporal, passado, real. Sua partilha traduz a dinâmica do devir como diferenciação e criação (LINS, 2005).

Leitor/autor, o sujeito que se constitui a partir de sua confrontação com o impossível pode tão-só ser um sujeito desejante. Ao invés de fechar a experiência no discurso, no significante, o desafio de reinventar o texto abre para a superabundância do inédito e incandescência do desejo. Confrontado à vida tatuada na própria escrita, o leitor fabrica sentidos, inventa o texto que está a ler; ele não é, contudo, um plagiador, mas um ladrão aberto às capturas: "Roubar é o contrário de plagiar, de copiar, de imitar ou de fazer como. A captura é sempre uma dupla-captura, o roubo, um duplo-roubo, e é isso que faz, não algo de mútuo, mas um bloco assimétrico, uma evolução a-paralela, núpcias, sempre 'fora' e 'entre'. Seria isso, pois, uma conversa” (DELEUZE; PARNET, 1998, p. 15).

Ao atribuir sentidos à escrita, o autor atravessa o texto enquanto que o leitor torna-se o intérprete, escritor do próprio texto. Não há assassinato do autor, porém, comunicação, encontro de intercessores. O leitor se coloca entre a organização dos valores do texto, sob a forma de um universo simbólico, e a autonomia de uma liberdade que não se deixa parar por nenhum objeto.

Ler o texto, ler o mundo é também um saber, resulta de um experimento que permite ao leitor advir em instância de desejo pela vontade do desafio: o experimento nunca é fechado pela comunicação hierárquica ou significante, nem por aquilo que o discurso recorta e encena. A escrita é o traço ou dobras que o sujeito dessa aventura deixa. Contradizendo o caráter efêmero e imediato da experiência, a escrita tende para a troca e a duração. Ela busca um convívio, eis porque os personagens criados pelo autor/leitor são sobremaneira conceitos engendrados de por uma escrita de invenção. Neste sentido, o ato de escrever, como tradução/traição da experiência em 
palavra, se inscreve numa ordem radical do gozo, isto é, numa potência de sobrevivência para além da morte: "só os organismos morrem".

O sentido produzido na leitura éo trabalho da memória e do esquecimento, axiomas fundamentais à invenção. Ele se situa no intermezzo, na passagem, não na substância das palavras, mas em sua margem, lá onde o desejo dos sujeitos aflora, articulando entre a linguagem e o corpo um inacreditável amor : a linguagem-corpo, em um devir-corpo do pensamento ainda não transformado em túmulo do pensamento pela escrita. Contudo, o amor é marginal, do mesmo modo que a escrita e a leitura nômade: entre-dois, isto é, em viagem.

Entre a experiência do sentido recebido e a ser inventado, o devir torna-se uma força positiva acoplada ao movimento e capturas de devires imperceptíveis ancorados, porém, em uma temporalidade inserida no conceito de ontologia concebido por Deleuze, sob os traços de Bergson. De fato, para Deleuze os presentes atuais são constituídos simultaneamente como presente e passado, eis porque em todos os presentes a integralidade do passado é conservada, ao mesmo tempo em que há um passado que nunca foi presente e um futuro que nunca será presente (DELEUZE, 1968, p. 97; BOUNDAS, 2005, p. 23)

Em síntese, almejo pensar com Deleuze e Guattari uma « semiótica contra-significante ", isto é, uma produção de signos que, porque rompe definitivamente com a função de significação, põe em xeque toda recuperação sob a forma de uma totalidade legítima e designadora, instaurando assim uma resistência, uma linha de fuga, uma brecha irremediavelmente aberta na ordem da linguagem (DELEUZE; GUATTARI, 1980, p. 149).

O DEVIR DJ DO LEITOR RIZOMÁTICO

Direi, pois, que todo bom leitor é uma espécie de DJ. O leitor rizomático, como o filósofo, é um artista, um construtor de conceitos cujo projeto instiga-o a praticar a free leitura ou ofree jazz: improvisação, intuição, roubo. O que o DJ faz em música se assemelha àquilo que o "leitor ladrão" faz do texto do autor, transformando-o em escrita bailarina. Ao mixar os trechos de discos, sequências, o DJ os agencia a fim de criar, com a ajuda desses pedaços disparates, o patchwork: conjunto qualquer formado de elementos heterogêneos "costurados" um nos outros.

Ora, mixar significa juntar as batidas de duas ou mais músicas na mesma velocidade, buscando uma fusão ou uma passagem de uma música para a outra. A banda sonora é composta de diversos trechos retirados de gravação ou sample "furtados" de outros discos para posterior colagem a outros trechos. O DJ parte de uma base, de uma raiz logo transformada 
por ele em rizoma. Eis porque é a mixagem que produz o inédito, sob a força de uma intensidade própria ao DJ, e que é o ápice de suas invenções e "conversas" com sujeitos melódicos, fragmentos de músicas apropriadas, diferenças que diferem.

A base, a aparente segurança, ou porto seguro sugerido pela raiz, é logo metamorfoseado em constelação de raízes que anunciam a emergência do rizoma. Não mais raiz, todavia, raízes, sem mestre-sala nem pontífice, sem abelha-rainha nem clonagem, sem hierarquias nem poder divino. Máquina de guerra sonora, o DJ como o filósofo é o bom ladrão; ele atribui ao roubo a força positiva de um devir próximo de Heráclito, gerando em sua arte as oposições de que decorrem os equilíbrios que sucedem num caos em permanente movimento, segundo uma medida/ desmedida e ritmos que expressam uma harmonia discordante em um caosmundo em permanente devir.

Não é isso que faz Deleuze, como foi aqui sugerido, com seus intercessores ou autores preferidos? Do mesmo modo, Derrida, leitor de Levinas, ao inventar o próprio texto do amigo filósofo, não é também, a sua maneira, um filósofo-leitor DJ? A conversa do DJ com os autores dos fragmentos de músicas, por ele roubado, celebra a captura, uma espécie de "fora" e "entre" sem os quais não há DJ, leitor de um livro-ritornelo, o livro das sonoridades embriagadas no qual ele encontra a Inventio.

O texto é, pois, uma irrupção viva de um outro que é também um sujeito eclodido, em devir; um sujeito sem subjetividade, autônomo no sentido grego: Nomos, não remete primeiro à lei. $\mathrm{O}$ verbo nemein significa "compartilhar" e, sobremaneira, atribuir a um rebanho uma parcela da pastagem. Nomas é o termo "que pasta" e nomos é "aquilo que é atribuído em partilha". O segundo sentido, "uso" e "lei", escapa à minha preocupação no presente contexto. Estou mais próximo da concepção dos romanos, que chamavam também "nômades", ou nomos as tribos errantes da África do Norte, sempre à procura de pastos para seus rebanhos nas regiões onde o capim é raro. Nomadizar e nomadismo estão associados à estrada. A procura de pastagem a compartilhar reúne, assim, em uma só palavra, o rumo a tomar na busca de sentido para o convívio. O DJ não seria o nômade das sonoridades embriagadas?

LEITOR: INTÉRPRETE OU COMENTADOR?

Diferentes teorias insistem sobre os três movimentos que compreendem toda leitura: percepção inicial do texto, interpretação intelectual e 
recepção afetiva; esses três movimentos são concomitantes e não separados. Assim, desde a primeira visão do texto, as dimensões intelectual e afetiva desempenham uma tarefa importante. Trata-se de inscrever o desejo do leitor na fábula, mediante personagens cujos pensamentos e reações podem não só representá-lo, mas determiná-lo. Sair da representação-prisão e da determinação-exílio demanda uma força positiva, uma captura, uma conversa que passa necessariamente pela agressão, em seu sentido primeiro, isto é, pelo movimento.

Manter, todavia, uma relação monstruosa com o autor, com o livro, não seria esse o destino do leitor? Deleuze, ao falar a respeito de suas primeiras leituras da filosofia dominada pela razão, pelo pensamento que pode ser pensado, escreveu: "Mas, minha principal maneira de me safar nessa época foi concebendo a história da filosofia como uma espécie de enrabada, ou, o que dá no mesmo, de imaculada concepção. Eu me imaginava chegando pelas costas de um autor e lhe fazendo um filho, que seria seu e, no entanto, seria monstruoso" (DELEUZE, 1992, p. 14).

A leitura rizomática põe o leitor numa situação de intérprete, no sentido musical do termo. Não se trata, pois, de repetir aquilo que o filósofo diz, que o escritor literário ou o pensador escrevem, mas produzir a semelhança. Que significa produzir a semelhança? Deixar aparecer a semelhança, criar a semelhança. Há uma diferença entre repetir e produzir. Ou melhor, cabe pensar uma repetição que seja produtora e não reprodutora, intérprete, e não comentadora. $\mathrm{O}$ intérprete é o oposto do comentarista: os próprios termos que os designa os separa, a saber: "Aquilo que distingue o com do comentador e o inter do intérprete. $\mathrm{O}$ primeiro oferece nas margens reputadas virgens um produto de acompanhamento, algo, diria vulgarmente, que 'combina', isto é, esse suplemento de informação ou de explicação que no limite do texto, nas suas margens, se une sem se tocar, sem realmente se misturar, mais ainda, sem transformá-lo ou alterá-lo" (MACHEREY, 1992, p. 12-3; LINS, 2007, p. 4-5).

Dito de outro modo, o comentador volta ao texto, pois ele pretende deixá-lo tal qual o encontrou; enquanto que o intérprete vai adiante, conduz o texto ora para as margens, ora para o meio, ora para o fora ou o dentro, numa escrita-experimento, com o rigor necessário próprio à interpretação como musicalidade cuja potência criativa exige uma espécie de ascese do texto, uma harmonia discordante, fazendo de sua leitura um ato produtor: relação às imposições exteriores, mais do que uma manipulação ou uma reprodução reputada conforme. O intérprete, como seu nome indica, se mantém no coração de um texto vivo, passando no meio da página, traba- 
lhando o texto um após outro, propondo-lhe uma forma de substituição: “ele o decifra, o executa, o realiza, o atualiza, dá essa 'apresentação' que se efetua tão-somente no presente" (MACHEREY, 1992, p. 12-3; LINS, 2007, p. 4-5).

Ao passado, à memória do sentido deformado em significante, aos casamentos selados com o texto pelo comentador, o leitor-intérprete, ignorando as obrigações às quais uma vulgata julga, de antemão, determinada, "opõe um presente em ato da letra: lemos um texto como se fosse inédito, como se acabasse de ser produzido" (MACHEREY, 1992, p. 12-3; LINS, 2007, p. 4-5).

A tentativa, pois, do leitor de dizer algo, de inventar, abre-o para uma profusão do inédito. Mas, como saber reconhecer a "boa" interpretação? [...] "a autêntica interpretação é justamente aquela que abandonou as pretensões abusivas de sentido, apreensões que fazem do próprio sentido o objeto de um dom e não o resultado de um trabalho, com os obstáculos e os riscos que deve enfrentar para conseguir" (MACHEREY, 1992, p. 12-3; LINS, 2007, p. 4-5).

Humberto Eco, por sua vez, pondera:

De fato, se não se pode dizer qual é a melhor interpretação de um texto, pode-se sublinhar às quais são erradas [...] Após a produção de um texto, é possível fazê-lo dizer muitas coisas [...], mas é impossível [...] fazê-lo dizer o que ele não diz. Muitas vezes, os textos dizem mais do que seus autores pretendiam dizer, contudo, menos do que muitos leitores incontinentes gostariam que dissessem (ECO, 1992, p. 130).

Cabe, uma vez mais, pensar a leitura como um rizoma e não como uma árvore. Não, a leitura não é um simples acesso ao mundo do imaginário - essencial, mas redutor -, do sonho, das belas letras, das palavras justas e lindas histórias. Lembro-me da frase de Francis Ponge: "Se eu escolhi escrever foi para agir sobre mundo e não ser agido por ele".

Fica claro que o poeta percebe a leitura e a escrita como um ato maior de emancipação, para além unicamente do lazer ou do comentário. O prazer, a sensualidade e, sobremaneira, o desejo, em si revolucionário e não arborescente, órfão e transversal, é a tradução maior do rizoma: interser, meio, mangue, o contrário da calma arborescente da piscina ou do aquário de salão desvitalizados cujas ondas e imanência foram confiscadas pelo mutismo de um olho sem luz nem gradiente: “o que está em questão no rizoma é uma relação com a sexualidade, mas também com o animal, com o vegetal, com o mundo, com a política, com o livro [...] com todo tipo de 'devires"' (DELEUZE; GUATTARI, 1992, p. 33). 
O leitor, inventor, produtor é o surfista da imanência, no sentido deleuziano: "Os surfistas não param de se insinuar nas dobras das ondas. Para eles a onda é um conjunto de dobras móveis [...] todos os novos esportes surfe, windsurfe, asa delta - são do tipo; inserção numa onda preexistente. Já não é uma origem como ponto de partida, mas uma maneira de colocação em órbita. $\mathrm{O}$ fundamental é como se fazer aceitar pelo movimento de uma grande onda, de uma coluna de ar ascendente 'chegar entre' em vez de ser origem de um esforço" (DELEUZE, 1992, p. 151).

Coluna de ar ascendente: é o que os surfistas chamam de baforada! É uma espécie de "Fora". Um fora mais longínquo que todo exterior, "se torce", "se dobra" de um dentro mais profundo que todo interior, e torna apenas possível a relação derivada do interior com o exterior. É essa torção que define "a carne" para além do corpo próprio e de seus objetos; uma carne cujas nervuras são a escrita-alma e cuja leitura só pode ser silenciosa, harmoniosa: o contrário, pois, do mutismo. É o olho do silêncio, o grito abafado de uma alma calejada, às voltas com as dobras e desdobras de um corpo-alma que não aguenta mais: alma fissurada da qual escorre a seivalivro, veias excitadas, estranguladas pelo gozo; alma que não mais pode guardar o silêncio de uma leitura que se passa do comentário para tornar-se melodia, fascinação musical, escrita bailarina, líquida, quente, escorregadia: poros e sonhos molhados. O leitor copula com a escrita e o livro torna-se uma fonte de gozo, para além do gênero - "gênero não me pega mais", de Clarice Lispector - e do modelo de humanidade tatuada pela queda, pela divida ou falta original; humanidade, pois, limitada ao homem e a mulher, ao "ser humano", humanidade, sem caosmundo: "A carne da sensação e a matéria do sublime estão inextricavelmente misturadas. A relação com o outro [aqui o escritor, o autor do livro] não procede por identificação de ícone preexistente, inerente a cada indivíduo [...] Não apenas eu é um outro, mas é uma multidão de modalidades de alteridade" (GUATTARI, 2000, p. 120).

O pássaro-surfista, leitor das ondas, voa; o pássaro ama voar. Deixar a superfície é para o surfista furar a onda, sem sacrifício nem martírio, e mergulhar no tubo que é pura imanência. Aqui, há algo comum entre Nietzsche e Deleuze: uma preocupação da superfície como motivação de um desenvolvimento de seus foras. Ora, essa preocupação com a superfície exige do surfista uma leitura silenciosa do livro-onda, com suas dobras e desdobras, sonoridade não linear de uma escrita que deve o tempo todo ser reescrita, porque líquida, ela não armazena verdades, não cultua nem bibliotecas nem 
museus. Essa não escrita virtual/atual constitui um capital primordial para o surfista-leitor de uma escrita liquida; ele pode, pois, dar-se ao luxo de se "embriagar com um copo d'água", de experimentar um devir-bêbedo abstêmio, deixando-se ninar pela onda que acaricia seu corpo, conduzindo-o a um desejo que deseja sempre desejar, sem falta, sem excesso, desejo como a vida: a imanência... uma vida.

Não haveria uma espécie de ascese nessa leitura silenciosa, força maior do surfista? Com a prática da leitura silenciosa, difundida sobremaneira no ocidente, no século IV, ao se aperceber que santo Ambrósio lê em silêncio, santo Agostinho contempla o olho do silêncio: o livro torna-se semelhante a um corpo cujo poro da pele seria o olho, mar ondeado na qual o surfista alheio a um "passado imemorial" ou a um "futuro messiânico" - esperar para esperar menos - põe-se na onda magra deleuziana, na boa onda: puro passado e eterna repetição da diferença, sob o signo de uma violência da sensação com a qual o surfista-leitor escreve seu próprio alfabeto (DELEUZE, 1981).

Nesse sentido, o surfista, excelente leitor do alfabeto das ondas, reinventa a própria onda fazendo de seu movimento, aparentemente repetitivo à exaustão, uma repetição engendrada como processo de contra-efetuação, marcada pela ética da intensidade e do acontecimento, mediante a qual o surfista almeja não aquilo que acontece - a emergência das ondas, sobremaneira, as magras, o tubo médio ou... gigante -, mas algo naquilo que acontece, como diria Deleuze (DELEUZE, 1969, p. 175).

O surfe é desenvolvimento da alegria pelo corpo; surfar é criar movimentos que agenciarão segundo uma superfície estabelecida. $\mathrm{O}$ movimento se cria na superfície e modifica os espaços. O que qualifica um bom surfista é a facilidade com a qual ele realiza seu movimento numa superfície de jogo pertencente a uma sedentariedade nômade do movimento e do tempo da onda.

Mas o surfista brinca de brincar com a onda, ultrapassando muitas vezes os limites da própria onda e das regras não estabelecidas de seus movimentos. Sua ação poderá superar a chegada da onda, fazendo dos limites o lugar de transmutação da conformidade e da violência da sensação da própria onda, gramática aquática com suas regras e limites. Essa superação das regras e do limite, que anula o acaso e recusa a duração legiferada das regras do mar, significa algo que Deleuze nomeia $\mathrm{O}$ jogo ideal e que, por minha parte, chamo de um movimento louco para um jogo ideal. Jogar apenas para além do acaso no acaso das próprias ondas é uma arte, um conhecimento de seu corpo e do corpo da onda: gorda ou magra, a onda tem um corpo, um corpo sem órgãos, uma leveza ativa, que é a própria leveza do ser em devir. 
Ora, um limite vale tanto pelo que ele contém quanto pelo que rejeita. Esse limite marca a sedentariedade do bom surfista à espreita da boa onda. Ele espera, e seu movimento itinerante se situa no interior dos limites. Nesse sentido, o surfista é o sedentário do esporte. Contudo, é parado que ele se movimenta mais: parar é ainda correr, é ter o corpo em movimento, em articulações que superam o espetáculo para se calar num silêncio que é sobremaneira leitura e comunicação com a onda.

Errante, seu movimento líquido encontra na onda o elemento que o insere na natureza: ele é natureza com a natureza. Essas dimensões do jogo ideal, do surfe ideal, se refletem, porém, longe das tábuas da lei ou das certezas: a própria onda é guiada por movimentos desterritorializados, inscritos numa escrita constituída por um alfabeto líquido, aqui, agora, já, provocando o tempo todo a anulação em vigor das próprias regras.

$\mathrm{Na}$ água não é apenas o bom surfista que brinca, cativa as ondas e a fúria do mar, numa escuta que supõe uma prudência intempestiva, inteiração, ação/reação, mas a incerteza das regras. $\mathrm{O}$ mar é o lugar por excelência da leitura móvel, errante, órfã; sua única verdade é a incoerência da verdade. $\mathrm{O}$ jogo ideal é a potência do acaso. $\mathrm{O}$ acaso para o surfista é o acaso do mar. A onda é o acaso do surfista, como o tubo é para ele o experimento da imanência.

Eis porque sua relação com a onda só pode ser amorosa, inclusive quando não há onda, quando as ondas gordas insistem numa continuidade que leva o surfista para outras paragens afetivas, mas que não é rejeito nem sublimação idiota, nem falta, todavia, diálogo com a não-onda, num devir nutrido pela positividade; é o contrário, pois, de um futuro refém de um acaso sem devir.

O surfista é a onda com a onda e não onda sobre a onda. Ele não existe apenas para aquilo que o tornará vencedor, mas se realiza afirmando o acaso. Temos aqui certamente uma bela definição do ser. O surfista se efetua não contra o acaso, mas com ele, nele: afirmações, pois, de todos os devires. O ser se realiza como univocidade pela plena afirmação do acaso como conjunto dos devires. Eis porque ele não conhece nem gramática, nem linguagem, nem língua, mas apenas o alfabeto. $\mathrm{O}$ alfabeto é tão-só um meio de aprender a pensar. O Código supõe um sentido de antemão inscrito no pensamento:

O alfabeto não supõe nenhum sentido constituído, mas unicamente o movimento virtual de sua produção. Não se adquire nem um saber, nem um método de pensar. Nada mais se faz que se iniciar a um movimento - um 
movimento que se encontra em toda parte onde há pensamento [...] Todas as Ideias comunicam no pensamento da singularidade. Contaminação de todo movimento de pensamento pelo movimento que se inicia às primeiras letras do alfabeto. Visto que se começa sempre pelo meio quando se adere perfeitamente ao movimento da onda (GIL, 2OO6, p. 25-6).

Como imaginar o surfista, fino leitor das ondas, sem a criatividadealiança da e com a própria onda? Ora, quem diz criação, diz perigo: correr perigo com arte, o contrário, pois, do niilismo ou da "vida besta", axioma fundamental do homo otarios, aquele que carrega uma árvore na cabeça e procura desesperadamente um começo, um pai, um ato inaugural: almeja ser adotado, quer ser escolhido, ao invés de escolher. O pensamento, porém, como a vida, é órfão, é pura criação. Só se pensa por necessidade, como motor dos aprendizados, interruptor mágico e automático da vontade de aprender. Direi, contudo, que a ideia de provocar a vontade de ler para motivar a aprendizagem é muito difundida, mas em geral pouco elaborada ou argumentada fora da estrutura, da árvore, do pensamento que pode ser pensado. Mormente, o prazer do texto, o prazer da leitura, passa necessariamente pelo novo, por algo que está por vir, pelo impensável no pensamento. De fato, a motivação (aquilo que faz sentido) é algo mais do que a vontade; é o que pensa o projeto, aqui o projeto de leitura:

A boa maneira para se ler hoje, porém, é a de conseguir tratar um livro como se escuta um disco, como se vê um filme ou um programa de televisão, como se recebe uma canção: qualquer tratamento do livro que reclamasse para ele um respeito especial, uma atenção de outro tipo, vem de outra época e condena definitivamente o livro. Não há questão alguma de dificuldade nem de compreensão: os conceitos são exatamente como sons, cores ou imagens, são intensidades que lhes convêm ou não, que passam ou não passam. Pop’filosofia, não há nada a compreender, nada a interpretar (DELEUZE; PARNET, 1998, p. 12).

Pode-se, igualmente, situar a leitura rizomática, à maneira de Guattari, numa ética e estética da transversalidade, de travessia, de saberessabores paralelos, da partilha, sob o signo de uma multiplicidade calcada nas trocas e vizinhanças, práticas e experimentos, pensamento e escrita inseridos na vida que passam tanto pela oralidade quanto pela escrita, sem oposição nem inclusão de uma pela outra. Não há nada a incluir, mas a compartilhar. Os exemplos do Jazz, do Rap ou do Hip-hop são formas 
experimentais marcadas por um devir que mescla e recicla, como em uma trasladação através de uma membrana, fazendo rizoma, produzindo um novo modo de ler, uma música, um novo tipo de amor acoplado ao movimento da leitura, multiplicador do tempo do desejo, cuja ressonância é dionisíaca (LINS, 2005a, p. 1229-57).

Diria, à guisa de in-conclusão, que um livro que reverbera é como um rio reconfortado pelo sol: a água corre, mas permanece na ocupação potente de seu leito que ela nutre e arruína, enquanto a superfície das miríades de faíscas fascina o olhar. Cada faísca, convite dançante, remete às outras para uma dispersão da luz rapidamente hipnótica. A corrente das palavras, seus cursos sábios produzem o feitiço ao qual vão então se fundir desejo e prazer, inscrevendo a tensão no gozo e o gozo na duração. É na realização do gozo, todavia, que o leitor encontra sua soberania. No final da palavra, no "final" do desejo, eis que o leitor chega ao silêncio.

Abandonado ao longo do texto ao risco e à alegria, o livro-castelo ou livro-surfe repousa agora na plenitude de seu novo vazio, um vazio habitado sem o qual não há nem autor nem leitor. Ler, escrever é caminhar para o silêncio do olho. $\mathrm{O}$ leitor erotizado por uma prática intensa de leitura sabe que toda escrita, não necessariamente "erótica", manifesta mediante uma mobilização especial, refinada, processual, delicada, bruta, cruel da carne, lendo/escrevendo, aquilo que é o eixo fundamental do gozo, a experiência do infinito: a intuição segundo Bergson, e o transcendental, segundo Deleuze.

Nessas condições, a leitura é entregue às turbulências atmosféricas, aos calores e arrepios do corpo-carne, aos eflúvios úmidos do silencio da epiderme e aos gritos abafados dos contrários em alianças e cópulas, ao mesmo tempo em que ondas e tubos gigantes confluem num leito comum, engendrando um livro-tempestade - como no extraordinário livro de Szendy (2004) -, um livro por vir.

For a RHIzOMatic Reading

ABstraCt: Proposal of a reading guided by experimentation of a random, nomad thought. The idea of rhizomatic reading allows to conceive that the manifestation of knowledge does not necessarily takes place in a "conscious" state of mind. It is about bringing up and reaching plateaus, folds and vanishing lines of a other-thought, a thought of difference, prompting the reader to interact in the vast ocean of sonorities and invention of new affections, becoming while reading the author/reader of the book itself, here understood as a book to be. 
KEYwORDs: Reading, rhizome, internet, alphabet, surf.

\section{REFERÊNCIAS}

BARTHES, Rolland. Critique et Vérité. Paris: Seuil, 1999. Original: 1966.

BOUNDAS, Constantin. Les stratégies différentielles dans la pensée deleuzienne. In: BEAULIEU, Alain (Org.). Gilles Deleuze - Héritage philsophique. Paris: PUF, 2005. DELEUZE, Gilles. Différence et Répétition.Paris : PUF,1968. . Conversações. Tradução de Peter Pál Pelbart. São Paulo: Editora 34, 1992. . Logique du sens. Paris: Minuit, 1969. . Francis Bacon Logique de la sensation. Paris: La Différence, 1981. . Qu'est-ce que la philosophie? Paris: Minuit, 1991. . Mil platôs. Tradução de Aurélio Guerra Neto e Célia Pinto Costa.

São Paulo: Editora 34, 2000. V. 1. . Mille Plateaux. Paris: Minuit, 1980.

DELEUZE, Gilles ; PARNET, Claire. Diálogos. Tradução de Eloísa Araújo Ribeiro, São Paulo: Escuta, 1998.

DERRIDA, Jacques. L'écriture et la différence. Paris: Seuil, 1967.

ECO, Humberto. Les limites de l'interprétation. Paris: Le livre de poche "Biblio essais", Paris : 1992.

FERRAZ, Silvio. Ritornelo: Composição passo a passo. OPUS, Revista da associação nacional de pesquisas e pós-graduação em música, Campinas, 2004.

GIL, José. L’alphabet de la pensée. In: Rue Descartes. Gilles Deleuze - Immanence et vie. Paris : Collège international de philosophie, PUF/Quadrige, 2006.

GUATTARI, Félix. Caosmose. Tradução de Ana Lúcia de Oliveira e Lúcia Cláudia Leão. São Paulo: Editora 34, 2000.

LINS, Daniel. Deleuze - Juízo e Verdade. Tradução de Fabien Pascal Lins. São Paulo: Annablume, 2004.

. Mangue's School ou por uma pedagogia rizomática. Educação \& Sociedade, Revista de Ciências da Educação, Campinas, v. 26, set./dez. 2005a.

. Razão nômade. Rio de Janeiro: Forense, 2005.

. LINS, Daniel. Expressão: Espinosa em Deleuze, Deleuze em Espinosa. Rio de Janeiro: Forense, 2007.

MALLARMÉ, Stéphane. Igitur: divagations, un coup de dés. Paris : Gallimard, 1976. 
MACHEREY, Pierre. Avec Spinoza - Etudes sur la doctrine et l'histoire du spinozisme. Paris: PUF, 1992.

SZENDY, Peter. Les prophéties du texte - Leviathan. Lire selon Melville Paris: Minuit, 2004. 
